\title{
Conservative Immigration Reform and Illegal Immigrants
}

\author{
Huiyun Tanga
}

\begin{abstract}
In 1996, Congress enacted Illegal Immigration Reform and Immigrant Responsibility Act of 1996 (IIRIRA). Actually, it was a conservative legislation. It not only tightened border control but also strictly limited the public benefits about illegal immigration. Why Congress enacted serious immigration legislation in the 1990s? Generally speaking, economic factor and politics played an important role in it. In details, several reasons can account for its conservatism: (1) The first reason is that the increase number of illegal immigration led to the high cost of state governments, many state governments complained it; (2) The second reason is the influence of 187 Act which deported illegal immigration in primary and high school and it produced chain effect for other states; (3) The third reason is political election, including Congress election and president campaign. 187 Act greatly influenced GOP (Grand Old Party) and Congress, which was controlled by GOP, tended to take serious measures to contain illegal immigrants. Did IIRRA work? In fact, it did not control illegal immigration. After 1990s, more and more illegal immigration entered into America and U.S. has become the nation with the most illegal immigrants in the world. Therefore, Congress should consider comprehensive immigration reform.
\end{abstract}

\section{Keywords}

Conservative immigration reform, illegal immigrants, 187 Act

Currently, how to deal with ten millions of illegal immigration is a hot issue in 2016 presidential election. GOP (Grand Old Party)'s popular presidential candidate Trump put up that the illegal immigration should be deported and U.S. should build a border wall between America and Mexico. He is popular among under middle class white people at present. However, many Latinos are very worried about it. In fact, Trump's idea toward illegal immigrants is very similar to GOP's immigration reform in the 1990s, merely Trump's views are more extremely.

In 1996, Congress, which was controlled by GOP promulgated Illegal Immigration Reform and Immigrant Responsibility Act of 1996 (IIRIRA), which is famous for it's conservatism. In the light of this legislation, there were many serious clauses toward illegal immigration, including border control and domestic enforcement. Does it work to contain to illegal immigration? As a matter of fact, it failed. Today, American immigration system is broken, how to enforce comprehensive immigration reform? This paper will answer question on the basis of taking IIRIRA as an example.

This paper is divided into four parts. The first part

\footnotetext{
aShanghai Academy of Social Sciences, China

Correspondent Author:

Huiyun Tang, Room 458, Institute of International Relations, No. 7th Huaihai middle road 622, Huangpu district, Shanghai, China

E-mail: huiyun1213@hotmail.com
} 
is about the context of IIRIRA; the second part analyses the content and characteristics of immigration legislation of 1996; the third part evaluates the effect of IIRIRA. Finally, the fourth part concludes the influence of IIRIRA and United States should learn lessons from it.

\section{CONSERVATIVE IMMIGRATION REFORM}

In the middle of 1990s, Congress enacted immigration reform, including legal and illegal immigration. Legal immigration reform was about skilled people, while illegal immigration reform paid attention to border control and limiting the public benefits of illegal immigration. In 1996, Congress enacted IIRIRA, which was a very serious legislation to control illegal immigrants. Actually, it is an also conservative legislation. The following reasons can explain it.

Firstly, there were some serious policies about strengthening border. For example, under this legislation, the people, who illegally stayed in the U.S. from 180 days to one year, would be not permitted to enter the U.S. by any legal status in three years; the people, who illegally stayed in the U.S. one year, would be not permitted to enter the U.S. by any legal status in 10 years; the people, who illegally entered the U.S. and delayed 180-365 days, would be deported for three years; the people, who illegally entered the U.S. and delayed 365 days, would be deported in 10 years. During this period, these people would not get visa; any people, who once illegally entered the U.S., would not have opportunity to reenter the U.S., these people would be deported once the legislation took in effect. Besides, on the basis of legislation, until 2000, Immigration National Service (INS) would annually add 1,000 patrol people in five years and the number of patrol people would reach 10,000 . What's more, INS should update machines and add helicopters and cars to strength patrol at night. INS should establish the documents for any people, who entered the U.S., and tracked the entering and existing records.
Furthermore, the fine was also improved. According to this legislation, aliens, who illegally entered the U.S. after April 1, will be fined 250 dollars. The most serious punishment is that alien, who illegally entered the U.S., will suffer five-year imprisonment and deportation (Fragomen 1997).

Secondly, there were some requirements about aliens, who wanted to legally enter the U.S.. They had to provide health certification and sponsors. For example, any people, who wanted to enter the U.S., must be vaccinated to prevent various infectious diseases such as mumps, measles, rubella, hepatitis B. Besides, any aliens, who wanted to legally enter the U.S., must have financial supporters. There were some requirements about financial supporters, such as at least 18 years and their income must be $125 \%$ of federal poverty line. The exception was that the financial supporters' income could be $100 \%$ of federal poverty line if they applied visas for their family. Supporters can look for the common guarantors if they applied visas for their relatives. The second financial supporters should satisfy the first requirement ${ }^{1}$. In 1997, the individual of federal poverty line yearly was 7,890 dollars; two people family was 10,000 dollars; three people family was 13,330 dollars; four people family was 16,050 dollars. So, financial supporters' income should be at least 9,862 dollars yearly for the individual, 13,000 dollars yearly for the two people family, 166,662 dollars yearly for the three people family, 20,062 dollars yearly for the four people family ${ }^{2}$.

Thirdly, there were serious enforcements about employer sanction. Actually, there are two reasons of illegal immigrants, one is illegally entering the U.S. and the other is legally entering the U.S., while their visas are expired. In practice, the half illegal immigrants are illegal entering; the left are because of expired visa. IIRIRA took serious measures in border control in order to resolve the first problem. It is necessary to enforce employer sanction and investigate the visa expiration problems in order to 
resolve the second reason of illegal immigrants. Therefore, according to this legislation, INS should organize 300 people to investigate visas' expiration in three years. In addition, the people, who made fraud documents, will be immediately deported. Employer sanction was firstly put up in Immigration Reform and Control Responsibility Act of 1986, according to this legislation, it was illegal if the boss employed illegal aliens, employers must submit many documents to testify their legal status. In 1996's legislation, it reduced the numbers of checking documents' employers. Social security card, green card, American passport, and employment authorization, which were authorized by INS, were valid certifications. While the records of birth, citizenship certification, the report of naturalization, and foreign passport were invalid (Wong 2006). Moreover, according to this legislation, telephone checking system should be built, bosses could join in this project voluntarily and they could call freely and check the status of employees. This project firstly was enforced in five states. In addition, according to this legislation, illegal immigrants should not enjoy public benefits, such as Food Stamp, AFDC (Aid to Families with Dependent Children), SSI (Supplemental Security Income), and so on. However, they could enjoy public education and emergent medical care.

Therefore, from the perspective of border control and employer sanction, IIRIRA was more serious than past immigration legislation. Especially in border control, for any aliens, they would not have chance to enter the U.S. if they once illegally entered the U.S., so it was a very conservative legislation.

\section{BACKGROUND OF ILLEGAL IMMIGRATION REFORM AND IMMIGRANT RESPONSIBILITY ACT OF 1996}

Illegal immigrants derived from 1970s and it was more serious in the 1990s, economical factor, together with politics led to the enactment of IIRIRA. In details, following reasons can explain it.

Firstly, in the 1990s, more and more illegal immigrants increased the burden of state government, thus, they often complained to Congress and federal government. According to immigration urban research institute, the federal deficit because of illegal immigrants was two billion dollars every year at that time, state government paid for the cost of illegal immigrants, including public education and medical care fees ${ }^{3}$. For example, in Illinois, the total cost for illegal immigrants was 187 million dollars, 5.7 million dollars was used for public health of illegal immigrants; three million dollars was used for public education of illegal immigrants, 48 million dollars was used for medical care of illegal immigrants. Illegal aliens enjoyed $82.22 \%$ emergent medical care. In educational consumption, total 101.9 million dollars was used for illegal children. In total 101.9 million costs, state governments paid for 29.2 million dollars, local government paid for 66.2 million dollars. So, 95.4 million dollars was not paid by federal government ${ }^{4}$. Actually, the educational cost in primary and middle school was the greatest. Compared with American, illegal children took up higher percentage in primary and middle school; state governments annually gave 5,000 dollars for every illegal child in the 1990s. Although some businessmen enjoyed the benefits of illegal immigrants and illegal aliens also consumed in local places. According to American tax system, federal government enjoys more percentage of tax. In other words, some businessmen got benefits from illegal aliens and paid for taxi, while the benefits from illegal immigrants were not transited into public cost of state governments, because federal government enjoyed benefits while state governments did not. On the contrary, state governments had to pay for public education and medical care of illegal aliens, because federal government was not responsible for the educational and medical service according to American federal system. So, illegal immigrants mainly influence state governments rather than federal government. 
Under this context, many governors, who are from California, Florida, Amazon, New Jersey, Illinois wrote the letter together to Senate committees chairman Robbert Byrd to complain the increasing cost of illegal immigrants. Besides, congressmen and administrative officers, who are from immigration regions, called for Congress to control illegal immigrants. For example, San Diego Border Supervised Committee pointed that San Diego paid 70 million dollars for illegal immigrants, including medical and public service, which was equivalent $16.7 \%$ tax, so San Diego Border Supervised Committee called Congress for limiting illegal immigrants enjoying public benefits, besides, federal government should provide aid to state governments and take measures to strength border control ${ }^{5}$. The governor of Florida-Hon Lawton complained that the cost of illegal aliens is one billion dollars every year ${ }^{6}$; senator Hutchison, who is from Texas, put up that INS should prevent and arrest illegal aliens and cancel their public benefits and establish the documents of aliens ${ }^{7}$. In 1994, California enacted 187 Act, while the Supreme Court refused it. The governor of California complained that the cost of illegal immigrants reached 1.8 billion dollars in 1996, which was why California government passed 187 Act, while Supreme Court overthrew it. For the reason that he suggested state governments should own power to check immigration ${ }^{8}$.

State governments took many measures to control illegal immigrants. On the one hand, state governments enacted serious legislation to deport illegal aliens, such as 187 Act of California. On the other hand, state governments asked the federal government for aiding them. In the $1990 \mathrm{~s}$, Congress authorized 1.8 billion dollars to state governments to offset the cost of criminal illegal aliens. In 1996, president authorized 100 million dollars to aid immigration education, including illegal immigrants. Meantime, federal government also provided 150 million dollars to offset the cost of emergent medical aid ${ }^{9}$.
Besides, illegal immigrants also led to crime issue. Forty-five percent (45\%) illegal aliens lived in California, there were $15 \%$ of jail population, approximate 1.6-2.3 million was illegal immigrants ${ }^{10}$. Furthermore, related interest groups also called for limiting illegal immigrants. For example, in 1995, Congress held the taxi of illegal immigration hearing, many interest groups called for controlling illegal immigration $^{11}$. In this hearing, National Council of La Raza thought immigration was useful for the nation, while they opposed illegal immigrants and they suggested the following measures to contain them: strengthening border control, reducing the number of visa, enforcing serious workers legislation, seriously enforcing employer sanction ${ }^{12}$. Agricultural interest groups opposed the increase of illegal immigration and welcomed the measure to control illegal immigration but the measure should satisfy the need of agricultural workers ${ }^{13}$. Human rights groups, environment groups, and ethnic groups supported free immigration policy while strongly opposed illegal immigration.

It was interesting that labor union changed the policy about immigration. In the past, labor union strongly opposed immigration, while labor union began to support the liberal immigration policy since 1990s. For example, United Farm Workers (UFW) opposed temporary workers in the 1940s and 1950s, they thought illegal workers influenced the benefits of legal workers and destroyed strike. In 1975, under the lobbying of Latino groups, UFW softened the policy and turned to only against illegal immigration from opposing the whole immigration. In the 1990s, labor unions opposed employer sanction, which was opposite in the 1980s. The reason why labor union changed their attitude toward immigration is that more and more immigrants joined in the labor union. Many labor unions, such as AFL-CIO (American Federation of Labor and Congress of Industrial Organizations) declared that labor union not only devoted to protecting the benefits of American workers but also 
protecting the benefits of immigrants' workers, including legal and illegal immigrants. In addition, some professional labor union also devoted to maintaining the benefits of immigrants workers. For example , CIWA (California Immigrant Workers Association), was established in 1987, the original aim of this organization was to help enforce amnesty policy and legalized workers can join in this organization. These organizations promote the protection of the immigrants' benefits (Jacobson and Geron 2011). Compared with labor union's liberal policy, the whole immigration policy was conservative in the 1990s.

Secondly, California government issued 187 Act in 1994. According to this legislation, any legal organization should report to juridical department of California if they suspected any people who were illegal; only American citizens or legal enters can enjoy public benefits, including middle school and high school education. Until 1996, any school should check any children and their parent's status. The children should not go to school if they were not legal. So, 187 Act seriously limited the public benefits of illegal immigrants, especially in the field of public education, teachers should report to immigration office if they suspected children's relatives were illegal. There was a great debate when it was enacted. Supporters thought it was a good legislation because state governments paid three billion dollars for illegal immigrants every year; the half of the cost was used for illegal children education (Margolis 1995). The opponents thought it would lead to discrimination against the ethnic groups. Schools, churches, and ethnic groups were against the bill. Ethnic groups, including Mexican Americans Legal Defense and Educational Founding and American Civil Free Federal Union together put up lawsuit (McDonnell 1999). Besides, other places, including Denver also opposed it; some Latin ethnic groups were against Disney, which locates in California (Suarez-Orozco 1996). Mexican government also opposed it (Martis 1994). The president Bill Clinton regarded 187 Act as the challenge to federal government's authority in immigration legislation and disagreed with it. (Philip 1995) Finally, the Supreme Court defied the legislation, in Supreme Court's opinion, 187 Act broke American warfare system and the state government did not have power to adjust the American warfare system. However, 187 Act was abolished until Democratic Party came to power.

187 Act produced chain reaction and influenced the other places of America, as a result, the idea of the whole society toward immigration was hostile and conservative immigration reform was enforced. The conservative immigration reform also influenced other places, such as Hazelton also took more serious legislation (Jacobson and Geron 2011). 187 Act also reflected the power struggle between the federal government and state governments. Federal government thought immigration legislation belongs to national security issue, while state governments were not satisfied with federal government's immigration legislation. The power struggle became more and more competitive with the increase of illegal immigrants in the 1990s.

Thirdly, election politics influenced immigration reform. There was a close relation between 187 Act and election politics. According to Los Angeles Times, Republic candidate Peter Wilson reelected governor and his competitor was Democratic candidate Kathleen Lynn Brown. At the beginning, Peter Wilson lagged behind Brown, but there was a great change after 187 Act, which was put up by Peter Wilson. In other words, 187 Act was the important tool for Peter Wilson's rerunning for governor (Decker and Weintraub 1994). However, 187 Act showed that illegal immigration should be resolved in the 1990s. Federal government should pass new legislation to control illegal immigrants, especially whether illegal immigrants should enjoy public benefits or not. Just as senator Dianne Feinstein said, he did not agree with 187 Act, but he hoped that Congress could take effective measures to control illegal immigration ${ }^{10}$. 
Besides, the election of Congress and president were also influenced by immigration policy.

In 1994, Congress faced midterm election; the republican chairman New Gingrich, concluded some lessons from Peter election and took both serious and conservative immigration policy. Then, republican party controlled House and Senate. As a result, Congress's policy toward immigration tended to conservative. Similarly, White House was also influenced in this political context (Newton 2008). Apart from all this, Bill Clinton began to run for re-election to the president in 1996.

In his eyes, he should reduce the quota of family together, while was not welcomed by ethnic groups (Gimpel and Edwards Jr. 1999). Additionally, Bill Clinton supported illegal immigrants should enjoy public education and emergent medical care (Sachs 1996). Taking into consideration, there were some serious measures on border control, while illegal immigrants can enjoy public education and emergent medical care in IIRIRA after the compromise between White House and Congress. It is notable that immigration issue has become election issue since 1990s. Prior to this, election was not related to immigration policy and there was not difference between GOP and Democratic Party. But everything has changed since 1990s. Peter Wilson madly and fully used illegal immigration to win election, which influenced the following political election.

\section{DID IT WORK}

On the basis of American Status Immigration Research Center, from 1990 to 2000, the number of illegal immigration has increased from 350,000 to 700,000 (Edwards Jr. 2006). Apart from that, according to the Department of Homeland Security, since 1996, more and more illegal immigrants came to the U.S., as following Figure 1 shows.

Thus, IIRIRA failed, why so serious and conservative legislation did not work? Two reasons can account for it, one is that there is something wrong with legislation itself, including border control and employer sanction, other reason is that enforcement is weak. Following can explain them.

Firstly, the most important characteristic of IIRIRA is strengthening border control. In the light of Provision 110, an electronic tracking system should be established. However, this system was hard to establish because of technical reason. Therefore, Congress had to delay the deadline. For example, in line with this legislation, electronic tracking system should be built in 1998. But in 1998, this system was not built. In 1998, in the 105th Congress, there was an agreement that Congress should extend the deadline of Provision 110 or abolish it (Krouse and Wasem 1998). In 1999, Congress revised the Provision 110 and put up that tracking system in land and sea should be built in 2001, while tracking system in air should be established before 1998. In 2000, Congress revised Provision 110 and came up that the tracking system in the sea, air, and land should be established step by step (Vina 2003). Consequently, it was difficult to establish electrical tracking system.

Why was it difficult to establish this system? On the one hand, money was not enough, INS evaluated that the cost of infrastructure was two to three billion dollars. In 1998, Congress authorized 130,000 dollars to enforce this project. At the same time, Congress also provided supernumerary 20 million dollars, but it was not fulfilled. In 1999, INS declared that they were lack of money. In 2000, Congress did not provide founding; however, Congress provided the average financial support according to founding project in 1998 (Krouse and Wasem 1998). Although Congress provided founding to INS, INS still had insufficient funds. On the other hand, there was inadequate implementation. Generally speaking, most of the illegal immigrants entered the U.S. by land. So land should be the most important place. However, land border was inadequate. Especially in the northern border, management was very loose. According to this 


\section{Drop in inflow of illegal immigrants}

The number of illegal immigrants in the U.S. declined to 11.1 million in March 2009 from a peak of 12 million in March 2007. This marked the first reversal in growth in two decades.

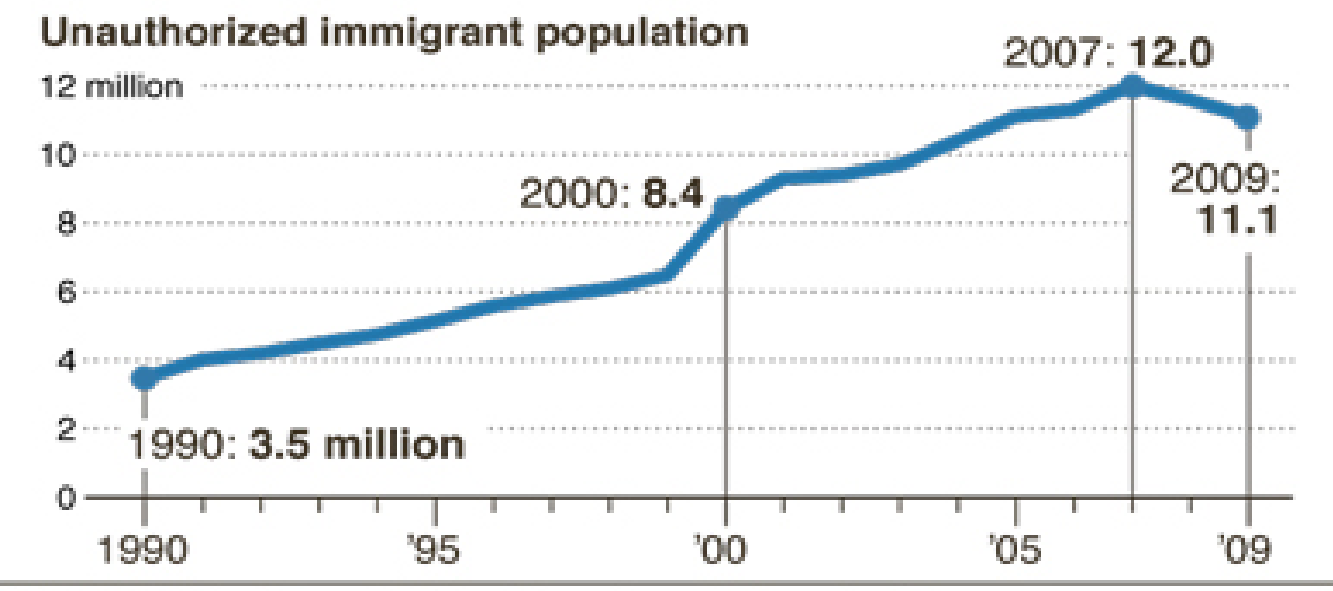

SOURCES: Pew Hispanic Center; Department of Homeland Security

AP

Figure 1. Drop in Inflow of Illegal Immigrants.

legislation, southern border was strengthened, while northern border was loose. Because since the establishment of NAFTA (North American Free Trade Agreement), some congressmen were worried that serious land border management would affect free trade. Based on this consideration, not only the deadline of implementation in land lagged behind the implementation both in air and sea but also checking border was inadequate in northern border. For instance, senator Steve King pointed that although IIRIRA had strengthened the southern border, while many illegal immigrants entered the U.S. from Canada border, so border control cannot reduce the number of illegal immigrants ${ }^{14}$.

Additionally, the implementation of the employer sanction was also weak. According to this legislation, electrical verification status system should be established, which was helpful for employers to check the status of employees. However, it was not realistic to build electrical verification status system.

\section{CONCLUSIONS}

In short, in the context of more and more illegal immigrants in the U.S., Congress enacted IIRIRA, whose aim was to reduce the number of illegal immigrants. Although it is a very conservative legislation, it does not achieve aim because of inadequate implement and lack of reality. As a result, Congress should enforce comprehensive reform, including strengthening enforcement and enacting realistic legislation.

Comprehensive immigration reform started in 2005 , however, it falls in deadlock now. As a matter of fact, both Bush and Obama actively pushed forward comprehensive immigration reform; particularly Obama put immigration reform as primary domestic policy in both administrations. However, he has not done immigration reform. As a result, he had to resort to executive order on immigration, then many state governments refused to implement it and more than 20 governors sued him. At present, Supreme Court 
has accepted lawsuit but not done last judgment.

Why comprehensive immigration reform is so difficult to promote? Actually IIRIRA plays an important role in comprehensive immigration reform. The greatest reason was polarization and there was big disparity between GOP and Democratic Party on immigration reform, which derived from IIRIRA. Merely the disparity between GOP and Democratic Party is greater than 1990s. Compared with 1996 immigration reform, comprehensive immigration reform has something in common with it. It was very similar that GOP controls House and Senate while there is a Democratic president. Consequently, it is difficult for Congress to pass comprehensive immigration bill.

Additionally, IIRIRA influences GOP's ideas toward illegal immigrants. In fact, two models about illegal immigrants were formed in GOP after IIRIRA. One is Peter Wilson model, which is to take serious measures to control illegal immigrants and oppose amnesty; another model is Bush model, which is to take comprehensive measures to contain illegal immigrants. IIRIRA reflects GOP's Peter Wilson model and it dominates in GOP at present. On the contrary, Democratic Party argues that illegal immigrants should own legalization channel. Consequently, comprehensive immigration is in stalemate.

Besides, immigration firstly became a political issue in election, if we look at the background of IIRIRA. At that time, GOP learned from Peter Wilson's election and enacted IIRIRA. Currently, in order to win election, GOP continues to take advantage of illegal immigrants, including 2014 midterm election and 2016 presidential election.

IIRIRA shows that conservative immigration reform cannot resolve immigration issue and reduce the number of illegal immigrants. Both GOP and Democratic Party should learn from lessons, and work together to resolve illegal immigration.

\section{Notes}

1. Retrieved (http://www.americanlaw.com/1996law.html).

2. Retrieved (http://migration.ucdavis.edu/mn/more.php?id= 1223_0_2_0).

3. Impact of illegal immigration on public benefit programs and the American labor force: Hearing before the Subcommittee on Immigration and Claims of the Committee on the Judiciary, House of Representatives, One Hundred Fourth Congress, first session, April 5, 1995, United States. Congress. House. Committee on the Judiciary. Subcommittee on Immigration and Claims, Washington: U.S. G.P.O (Government Printing Office) Supt. of Docs., Congressional Sales Office, 1996, pp. 13-24.

4. Increasing Costs of Illegal Immigration, Special Hearing, June 22, 1994. Committee on Appropriations. Senate, pp. 6.

5. Proposals to reduce illegal immigration and control costs to taxpayers: Hearing before the Committee on the Judiciary, United States Senate, One Hundred Fourth Congress, first session, on S. 269 ... March 14, 1995, United States. Congress. Senate. Committee on the Judiciary. Washington: U.S. G.P.O Supt. of Docs., Congressional Sales Office, 1996, pp. 305-306.

6. Proposals to reduce illegal immigration and control costs to taxpayers: Hearing before the Committee on the Judiciary, United States Senate, One Hundred Fourth Congress, first session, on S. 269 ... March 14, 1995, United States. Congress. Senate. Committee on the Judiciary. Washington: U.S. G.P.O Supt. of Docs., Congressional Sales Office, 1996, pp. 46.

7. Proposals to reduce illegal immigration and control costs to taxpayers: Hearing before the Committee on the Judiciary, United States Senate, One Hundred Fourth Congress, first session, on S. 269 ... March 14, 1995, United States. Congress. Senate. Committee on the Judiciary. Washington: U.S. G.P.O: For sale by the U.S. G.P.O Supt. of Docs., Congressional Sales Office, 1996, pp. 6-8.

8. Field hearing on public benefits, employment, and immigration reform: Hearing before the Committee on Economic and Educational Opportunities, House of Representatives, One Hundred Fourth Congress, second session, hearing held in San Diego, CA, February 22, 1996, United States. Congress. House. Committee on Economic and Educational Opportunities. Washington: U.S. G.P.O Supt. of Docs., Congressional Sales Office, 1996, pp. 27-28.

9. Impact of illegal immigration on public benefit programs and the American labor force: Hearing before the Subcommittee on Immigration and Claims of the Committee on the Judiciary, House of Representatives, One Hundred Fourth 
Congress, first session, April 5, 1995, United States. Congress. House. Committee on the Judiciary. Subcommittee on Immigration and Claims. Washington: U.S. G.P.O: For sale by the U.S. G.P.O Supt. of Docs., Congressional Sales Office, 1996, pp. 18-20.

10. Proposals to reduce illegal immigration and control costs to taxpayers: Hearing Before the Committee on the Judiciary, United States Senate, One Hundred Fourth Congress, first session, on S. 269 ... March 14, 1995, United States. Congress. Senate. Committee on the Judiciary. Washington: U.S. G.P.O Supt. of Docs., Congressional Sales Office, 1996, pp. 4-6.

11. Proposals to reduce illegal immigration and control costs to taxpayers: Hearing before the Committee on the Judiciary, United States Senate, One Hundred Fourth Congress, first session, on S. 269 ... March 14, 1995, United States. Congress. Senate. Committee on the Judiciary. Washington: U.S. G.P.O Supt. of Docs., Congressional Sales Office, 1996, pp. 134.

12. Proposals to reduce illegal immigration and control costs to taxpayers: Hearing before the Committee on the Judiciary, United States Senate, One Hundred Fourth Congress, first session, on S. 269 ... March 14, 1995 , United States. Congress. Senate. Committee on the Judiciary. Washington: U.S. G.P.O Supt. of Docs., Congressional Sales Office, 1996, pp. 179.

13. Proposals to reduce illegal immigration and control costs to taxpayers: Hearing before the Committee on the Judiciary, United States Senate, One Hundred Fourth Congress, first session, on S. 269 ... March 14, 1995, United States. Congress. Senate. Committee on the Judiciary. Washington: U.S. G.P.O Supt. of Docs., Congressional Sales Office, 1996, pp. 289.

14. Rep. Zoe Lofgren holds a hearing on immigration reform, section: Capitol Hill hearing testimony, committee: House Judiciary, subcommittee: Immigration, Citizenship, Refugees, Border Security and International Law, hearing: "Shortfalls of 1986 Immigration Reform Legislation", Committee on House Judiciary, Subcommittee on Immigration, Citizenship, Refugees, Border Security and International Law.

\section{References}

Decker, C. and M. D. Weintraub. 1994. "Wilson Savors Win; Democrats Assess Damage." Los Angeles Times, November 10 , p. 1.
Edwards Jr., J. R. 2006. Two Sides of the Same Coin: The Connection Between Legal and Illegal Immigration. Retrieved (http://www.cis.org/articles/2006/back106.html).

Fragomen Jr., A. T. 1997. "The Illegal Immigration Reform and Immigrant Responsibility Act of 1996: An Overview." International Migration Review 31(2):438-460.

Gimpel, J. G. and J. R. Edwards Jr. 1999. The Congressional Politics of Immigration Reform. Boston, MA: Allyn and Bacon.

Jacobson, R. and K. Geron. 2011. Unions and the Politics of Immigration. Retrieved (http://sdonline.org/48/ unions-and-the-politics-of-immigration).

Krouse, W. J. and R. E. Wasem. 1998. Immigration: Visa Entry/Exit Control System. Washington D.C.: Library of Congress. Congressional Research Service.

Margolis, J. R. 1995. "Closing the Doors to the Land of Opportunity: The Constitutional Controversy Surrounding Proposition 187." The University of Miami Inter-American Law Review 26(2):368-369.

Martis, N. H. 1994. 187 Undocumented Immigrants. Ineligibility for Public Services. Verification and Reporting. Sacramento, CA: California Voter Foundation.

McDonnell, P. J. 1999. "Davis Won’t Appeal Prop. 187 Ruling, Ending Court Battles.” Los Angeles Times, July 29, p. 1.

Newton, L. 2008. Illegal, Alien, or Immigrant: The Politics of Immigration Reform. New York: New York University Press.

Philip, M. 1995. "Proposition 187 in California." International Migration Review 29(1):258-259.

Sachs, L. 1996. "Treacherous Waters in Turbulent Times." Social Justice 23(3):65.

Suarez-Orozco, M. M. 1996. "California Dreaming: Proposition 187 and the Cultural Psychology of Racial and Ethnic Exclusion." Anthropology \& Education Quarterly 27(2):161.

Vina, S. R. 2003. Statutory Analysis of Section 110 of the Illegal Immigration Reform and Immigrant Responsibility Act of 1996. Washington D.C.: Congressional Research Service Reports.

Wong, C. 2006. Lobbying for Inclusion: Rights Politics and the Making of Immigration Policy. Palo Alto, CA: Stanford University Press.

\section{Bio}

Huiyun Tang, Ph.D., assistant researcher, Shanghai Academy of Social Sciences, China; research fields: American politics, American immigration policy, and U.S.-China relations. 